\title{
CULTIVATION OF MEDICINAL AND AROMATIC PLANTS IN HEAVY METAL- CONTAMINATED SOILS
}

\author{
LYDAKIS-SIMANTIRIS N. ${ }^{1, *}$ \\ FABIAN M. ${ }^{2}$ \\ SKOULA M. ${ }^{2}$
}

\author{
${ }^{1}$ Department of Environmental and Natural Resources Engineering \\ Technological Education Institute of Crete \\ 3 Romanou str., 73133, Chania, Crete, Greece \\ ${ }^{2}$ Mediterranean Agronomic Institute of Chania, Crete \\ Alsyllio Agrokepiou, PO Box 85, Chania, 73100, Crete, Greece
}

Received: 09/11/2015

Accepted: 29/02/2016

Available online: 03/06/2016

\section{ABSTRACT}

The growing number of polluted land areas makes the question of rehabilitation and safe/effective use of these areas increasingly imperative. For land polluted by heavy metals, the possibility of transferring the toxic pollutants to humans through the food chain further increases the importance of the safe management of polluted lands. We examined the possibility of using heavy metal-polluted areas for growing specific aromatic plants, which can be used either as food herbs/infusions, or to produce high value products. In a pot experiment, chamomile, sage and thyme plants were exposed to a range of concentrations of $\mathrm{Cd}, \mathrm{Pb}$, and $\mathrm{Ni}$ in the soil. Toxic metal levels were determined in the roots, leaves and flowers (for chamomile) of the plants. All three plants accumulated relatively high amounts of metals in their roots, whereas the aboveground parts exhibited lower accumulation capacity. Regardless the levels of metal accumulation, the quality of essential oils from chamomile, sage, and thyme was not affected and in all cases the extracted essential oils were free of heavy metals. Our results suggest that the aromatic plants under study cannot be consumed either as food additives or as infusions. However, under strict control of the cultivations, heavy metal-contaminated areas can be used for the production of essential oils from aromatic plants.

Keywords: Soil contamination, heavy metals, aromatic plants, essential oil, phytoextraction

\section{Introduction}

The major sources for heavy metals and metalloids in soils are the soil parent material and anthropogenic activities. Except special cases, the distribution of heavy metals in earth's crust originating from parent material does not cause any problems in ecosystems and certainly cannot be considered as pollution. On the other hand, heavy metals and/or metalloids originating from anthropogenic activity (i.e. industry, intensive agriculture, mining etc.), usually are distributed, or accumulated at non-physiological levels, in specific areas where the activity takes place. Finally, a polluted site is created, which affects the ecosystem, possibly the quality of surface and underground water, and of course, the communities living in these areas. This environmental problem has become a serious concern the last few decades, due to expansion of the affected areas and the consequent threat of local ecosystems and natural resources. In general, urban areas usually show high levels of $\mathrm{Pb}, \mathrm{Cd}, \mathrm{Cu}, \mathrm{Ni}$, and $\mathrm{Zn}$ contamination, mainly from traffic, paint, and other non-specific urban sources. The total heavy metal content in a soil is the sum of the concentrations of the elements originating from the parent material (lithogenic source) and inputs from 
the various anthropogenic sources, (i.e. atmospheric deposition, intensive agriculture, traffic, industry, mining, livestock manures, urban wastes etc.). The accumulation of heavy metals through anthropogenic activities over the years results heavily contaminated soils, unsuitable for agriculture. In many cases, in these contaminated areas rehabilitation processes take place. Conventional techniques, used for the remediation of heavy metal-contaminated soils, carry several problems such as removing the contaminated soil, transporting it to either a safe storage place or to a processing unit for heavy metal removal. These practices result to high (usually prohibitively high) cost, high labor demand, whereas the benefits from their application are not always the expected (Raskin and Ensley, 2000; Butcher, 2009; Ali et al, 2013; Bolan et al., 2014; Mahar et al., 2016). On the other hand, phytoremediation has emerged as an alternative technique for soil decontamination (Butcher, 2009; Meagher, 2000; Cunningham and Ow, 1996). Phytoremediation refers to "the use of plants and associated soil microbes to reduce the concentrations or toxic effects of contaminants in the environment" (Greipsson, 2011). In general. phytoremediation can be applied for different types of contaminants, such as heavy metals, radionuclides, organic pollutants etc. Depending on the case, a variety of approaches can be followed (phytoextraction, phytofiltration, phytostabilization, phytovolatilization, phytodegradation, etc), however several limitations exist for their application: (i) not many plants are heavy metal hyperaccumulators, (ii) usually these plants accumulate selectively one, or at best very few of the several elemental contaminants in the soils, (iii) in order for the hyperaccumulators to be effective for phyroremediation, they need to produce large biomass, and (iv) specific conditions in a contaminated area may not support the cultivation of a hyperaccumulating plant suitable for phytoremediation (for comprehensive reviews see Raskin and Ensley, 2000; Butcher, 2009; Ali et al, 2013; Bolan et al., 2014; Mahar et al., 2016).

It is not uncommon in areas with intensive industrial or mining and smelting activity, unattended heavy metal-contaminated fields to be found. Besides the fact that these fields remain unused, eventually, plants tolerant to high contamination levels will start to grow and proliferate in them, with the danger of the introduction of heavy metals in the food chain through grazing. Thus, the idea of using heavy metalcontaminated land for alternative agriculture for the production of final products with high economic value has a lot of profound potential benefits.

This work aims to contribute to the discussion whether heavy metal contaminated fields could be used to grow specific plants (in this case medicinal aromatic plants) with high-added value products, and to which extend these plants could be used. Positive answers to this question give the possibility to convert a serious problem (contaminated field) to a potentially profitable source, given that all the precautions are taken in order to keep safety to the highest level. Products directly related with aromatic plants are used extensively in food, pastry, condiment, cosmetics and other industries. Also, aromatic plants are used in traditional medicine since the first steps of human civilization (Tapsel et al., 2006). It needs to be noted that the point of view of this article does not include the utilization of the aromatic plants under examination as phytoextraction tools, since neither their hyperaccumulation capacity, nor their biomass are such to justify such use (McGrath and Zhao, 2003).

Three aromatic plants, namely chamomile (Matricaria recutita), sage (Salvia officinalis), and thyme (Thymus vulgaris), very common in countries with temperate climatic conditions, but also extensively used since ancient years both for their medicinal properties and as food supplements (Lu and Foo, 2001; McKay and Blumberg, 2006; Rubio et al, 2013; Tapsel et al., 2006), were examined in a pot experiment with soil contaminated by a wide range of $\mathrm{Cd}, \mathrm{Pb}$, and Ni concentrations. The accumulation of these metals in roots, leaves and flowers (only for chamomile) was determined and the Bioaccumulation factors (BAF) and Translocation factors (TF) were also estimated. Essential oils were extracted from the aboveground parts of these plants and their quality and heavy metal content were determined.

Cadmium is considered among the most toxic heavy metals and it has attracted a lot of attention in environmental science, soil science and agriculture (Andersen and Kupper, 2013; Smolders and Mertens, 2013; Tran and Popova, 2013). It is naturally present in most of soils as a divalent cation at concentrations usually within the range of $0.1-1.0 \mathrm{mg} \mathrm{kg}^{-1}$, but much higher and much lower values have also been reported. Since last century, these values exhibit an incremental trend because of the additions through 
atmospheric depositions and the use of phosphoric fertilizers and sewage sludge in agriculture. Also, Cd mining, production, use and disposal are the major anthropogenic sources of $\mathrm{Cd}$, which finally end up as contamination in the soil. World Health Organization (WHO) recommended level for $\mathrm{Cd}$ in aromatic plants is $0.3 \mathrm{mg} / \mathrm{kg}$ dry weight (WHO, 1998).

Lead is considered as the second most hazardous substance, after arsenic, by the Agency for Toxic Substances and Disease Registry (ATSDR, 2003). It is believed to be the first element extracted by man from its ores and it has been extensively used over the centuries. This fact caused extensive pollution of surface soils, both on local level due to mining and smelting, and globally by addition of organic $\mathrm{Pb}$ compounds in petrol, sewage sludges, and fertilization. Lead binds strongly on humic material in soils rich in organic matter and on iron oxides in mineral soils, and, depending on the conditions, is released in the soil solution (Steinnes, 2013). WHO recommended highest level in aromatic plants is $10 \mathrm{mg} / \mathrm{kg}$ d.w. (WHO, 1998).

Besides its natural abundance ( $21^{\text {st }}$ most abundant element in Earth's crust), nickel is also released in the environment through metal mining and smelting, various industrial activities like metallurgy and electroplating, fossil fuel burning as well as through applications of fertilizers and organic manures in agriculture. Nickel is considered as a micronutrient for plants, thus WHO has not set acceptable levels for $\mathrm{Ni}$ concentrations in plants, however, in high concentrations in soils $\mathrm{Ni}$ is toxic for plants (Chen et al., 2009).

\section{Materials and methods}

\subsection{Plant material}

The total experimental period was six months (from November to May). Plants were produced from seeds sown in a tray with mixture of compost for six weeks. Then the plantlets were transplanted in plastic pots containing one litre of compost (Klausman, Potgrond P blocking substrate), where they stayed to grow for eight more weeks. Then, appropriate volumes of stock solutions of the nitrate salts of $\mathrm{Cd}, \mathrm{Pb}$, and Ni were added to the soil, through irrigation, once for the total experimental period. The final total concentrations of the metals in the soil were: $\mathrm{Cd}$ 1, 3, 10, $30 \mathrm{ppm}, \mathrm{Pb} 60,180,600,1800 \mathrm{ppm}$, and Ni 20, 60, 200, 600 $\mathrm{ppm}$. These concentrations were selected in order to avoid lethal effects on the plants. Five pots with plants were prepared for each condition. Care was taken to maximize the homogeneity of the heavy metal application in the soil, as well as to keep the irrigation procedure stable and to avoid leachates. The experiment lasted six weeks for Matricaria recutita and twelve weeks for Thymus vulgaris and Salvia officinalis after heavy metal contamination of the soil.

\subsubsection{Metal concentration in plant tissues}

Roots and leaves (and flowers of chamomile) were harvested at the end of the experiment and their fresh weight was measured. Then, the samples were dried at $65{ }^{\circ} \mathrm{C}$ for 40 hours, and their dry weight was determined. $1 \mathrm{~g}$ of leaves or $0.5 \mathrm{~g}$ of roots or flowers was ashed in crucibles at $500{ }^{\circ} \mathrm{C}$ for 4.5 hours. The ash was dissolved in $10 \mathrm{ml} \mathrm{HCl} 2 \mathrm{~N}$, where 2 drops of $\mathrm{CHNO}_{3}$ were added. Finally, the acidic solution was filtered and diluted to $50 \mathrm{ml}$ (leaves) or $25 \mathrm{ml}$ (roots or flowers). Metal concentrations were determined by ICP-Atomic Emission Spectrometry (Leeman Labs, TS SPEC). Three measurements were carried out on each sample and five samples were prepared for each condition. Freshly prepared standard solutions were used for the calibration curves.

\subsubsection{Essential oils}

Chamomile flowers, sage leaves and thyme leaves were air dried in the shade, in a clean, well aerated room. Then, they were subjected to a micro steam distillation-extraction treatment with a Clavenger type distillation apparatus. Essential oils were kept in small, air-tight glass containers until analysis. For qualitative and quantitative analysis of the essential oil content, head space analysis and GC-MS were used, respectively. Head space analysis was carried out with a HP5890 II GC-FID coupled with a head space 
analyser. Each sample (200 mg of chamomile samples and $50 \mathrm{mg}$ of sage and thymus samples) was retained in the headspace oven for $30 \mathrm{~min}$ at $90^{\circ} \mathrm{C}$ and then extracted with a carrier gas (He) at $38 \mathrm{~cm} \mathrm{~s}^{-1}$ and transferred to the $\mathrm{GC}$ at $100^{\circ} \mathrm{C}$. The split ratio was $1: 50$ and a DB5 column was used. GC-MS analysis was performed on the same plant material from the headspace GC by a GC-MS (HP8980 II GS coupled to VGTRIO 2000 MS). Three repetitions of the whole procedure (essential oil extraction, head space analysis, GC-MS) were carried out and the results in this work are the mean values of the obtained measurements. Heavy metal determination in essential oils was carried out after extraction of essential oils by steam distillation/extraction of dry tissue and subsequent dry ashing. $\mathrm{HCl} / \mathrm{HNO}_{3}$ solution was used to dissolve the ash and ICP spectrometry was carried out for metal determination (three repetitions).

\subsection{Soil analysis}

Soil samples were collected before planting (control samples) and two days after the addition of the heavy metals. Control (uncontaminated) soil samples were also collected from Chania countryside, far away from any anthropogenic activity. The samples were dried at $37{ }^{\circ} \mathrm{C}$ for $36 \mathrm{~h}$ and then the total and the plant-available heavy metal content were determined. For the total content, $0.1 \mathrm{~g}$ of soil in $4 \mathrm{ml}$ of $\mathrm{CHNO}_{3}$ was digested in a microwave oven (Anton Paar). The digest was then diluted with distilled water to $50 \mathrm{ml}$. For the available heavy metals, extraction with the DTPA method was carried out. Briefly, the Lindsay and Norvell method (Lindsay and Norvell, 1978; Amacher, 1996) was used for the extraction of the plantavailable heavy metals by chelation with $0.005 \mathrm{M}$ diethylenetriaminepentaacetic acid, DTPA, in a buffer containing also $0.1 \mathrm{M}$ triethanolamine and $0.01 \mathrm{M} \mathrm{CaCl}_{2}, \mathrm{pH} 7.3 .10 \mathrm{~g}$ of soil was shaked with $20 \mathrm{~g}$ of the extractant for $2 \mathrm{~h}$ and then filtration and proper dilution took place. All the solutions were then analyzed by ICP-AES.

\section{Results and Discussion}

Bioavailability of metals in soils depends on several chemical and physicochemical parameters (such as $\mathrm{pH}$, macronutrients content, water content, redox status etc.) and the type of the soil (see also Cataldo and Wildung, 1978). For the assessment of the accumulation of metals in plants, it is important to determine the amount of the plant-available metals in the soil. Table 1 presents the calculated concentrations of heavy metals after their addition to the soil, and the corresponding available concentrations as they were determined in the DTPA extracts of the particular soil mixture we used. Note that the control soil, with no heavy metal additions, contained some amount of all heavy metals under examination in their bioavailable form. In all cases, the amount of plant-available heavy metals was a fraction of the total concentration. Each given value is the mean of five measurements. The total heavy metal content of the soils after the heavy metal additions was determined in the soil digests and a good correlation between the obtained data and the calculated amounts was observed in all conditions (data not shown). This result suggests that the added heavy metals here homogenized in the soil.

Table 1. Plant-available heavy metals vs. added heavy metals in the soil*.

\begin{tabular}{ccccccccc}
\hline Metal & $\begin{array}{c}\text { Added } \\
\text { (ppm) }\end{array}$ & $\begin{array}{c}\text { Available } \\
\text { (ppm) }\end{array}$ & Metal & $\begin{array}{c}\text { Added } \\
\text { (ppm) }\end{array}$ & $\begin{array}{c}\text { Available } \\
\text { (ppm) }\end{array}$ & Metal & $\begin{array}{c}\text { Added } \\
\text { (ppm) }\end{array}$ & $\begin{array}{c}\text { Available } \\
\text { (ppm) }\end{array}$ \\
\hline $\mathrm{Cd}$ & 0 & 0.167 & $\mathrm{~Pb}$ & 0 & 6.95 & $\mathrm{Ni}$ & 0 & 0.643 \\
\hline $\mathrm{Cd}$ & 1 & 0.875 & $\mathrm{~Pb}$ & 60 & 13.7 & $\mathrm{Ni}$ & 20 & 8.43 \\
\hline $\mathrm{Cd}$ & 3 & 1.35 & $\mathrm{~Pb}$ & 180 & 28.7 & $\mathrm{Ni}$ & 60 & 22.7 \\
\hline $\mathrm{Cd}$ & 10 & 2.57 & $\mathrm{~Pb}$ & 600 & 36.2 & $\mathrm{Ni}$ & 200 & 77.2 \\
\hline $\mathrm{Cd}$ & 30 & 10.1 & $\mathrm{~Pb}$ & 1800 & 188 & $\mathrm{Ni}$ & 600 & 153 \\
\hline
\end{tabular}

*The values of the available heavy metals are the means of five measurements.

The contamination levels in this study did not cause any serious morphological alterations to the plants, and certainly, any changes observed by careful measurement of the plants' height or number of branches and leaves were not such that they could distinguish contaminated from non-contaminated plants. In general, in all conditions tested, the three aromatic plants grew quite normally (and in some heavy metal 
concentrations even better than controls) with only minor changes which can be summarized to the following: Cadmium affected the height of chamomile plants, only at the highest concentration in the soil, whereas it had no considerable effects on sage and thyme. Medium concentrations of $\mathrm{Pb}$ caused slight increase of chamomile height and a small decrease of the number of leaves of sage, whereas it had no effects on thyme. All three plants grown in Ni-contaminated soil exhibited larger size, and correspondingly, increase of biomass.

\subsection{Accumulation of heavy metals in plant tissues}

Table 2 presents data on the accumulation of the three metals under study in the flowers (chamomile only), roots and leaves of chamomile sage and thyme.

\subsubsection{Chamomile}

Table 2 and Fig. 1 ( $\mathrm{A}, \mathrm{B}, \mathrm{C})$ present data on the accumulation of $\mathrm{Cd}, \mathrm{Pb}$ and $\mathrm{Ni}$, respectively, in the flowers, roots and leaves of chamomile. The major amount of the accumulated $\mathrm{Cd}$ was stored in the roots (Fig.1A), however significant amounts of the heavy metal were observed in the aboveground edible tissues (leaves and flowers). In all tissues examined, the accumulated $\mathrm{Cd}$ increased as the soil $\mathrm{Cd}$ concentration increased.

Similar behavior of chamomile has been observed in a hydroponics experiment with $\mathrm{Ni}$-enriched media, by Kováčik et al., (2009). Data in Table 2 indicate that even at the residual Cd concentration of the control sample, there was accumulation of the toxic metal in all three tissues, higher than the accepted levels set by WHO (0.3 $\mathrm{mg} / \mathrm{kg}$ d.w.).

The result of the control sample was checked with soil and wild chamomile samples, collected from the countryside of Chania prefecture, far away from any anthropogenic activity. Analysis of these samples gave consistently $[\mathrm{Cd}]<0.1 \mathrm{ppm}$, both for total $\mathrm{Cd}$ in the soil and for $\mathrm{Cd}$ content in flowers and leaves (data not shown). The Bioaccumulation Factor (BAF, [metal $\left.]_{\text {tissue }} /[\text { metal }]_{\text {soil }}\right)$ and the Translocation Factor (TF, [metal $\left.]_{\text {tissue }} /[\text { metal }]_{\text {roots }}\right)$ of the accumulation of the three heavy metals in the tissues of chamomile are presented in Table 2 . BAF's $>1$ indicate hyperaccumulation capabilities of the plants. As shown in Table 2, concentration of $\mathrm{Cd}$ in the flowers and leaves of chamomile exceeds the total $\mathrm{Cd}$ concentration in the soil only for the two lower contamination levels, whereas plants grown at higher $\mathrm{Cd}$ contamination levels did translocate more $\mathrm{Cd}$ to their aboveground tissues, but not as much as it is needed in order to be characterized as "hyperaccumulators". Taking into account that the amount of the plant-available metals in the soil solution depends on many chemical and physicochemical soil parameters (Alloway, 2013), and the fact that different characteristics of the same species (i.e. ploidity, diploid vs. tetraploid plants) may affect the toxic metal accumulation (Kováčik et al., 2012), our observation could rationalize the different conclusions reached by researchers, whether chamomile is a Cd hyperaccumulator or a $\mathrm{Cd}$ excluder (Chizzola and Mitteregger, 2005; Kováčik et al., 2006; Masarovičová and Králová, 2007; Masarovičová et al. 2010). Translocation factors were also above 1 only for the lowest $\mathrm{Cd}$ contamination level in the soil, showing the rather limited capability of chamomile to transfer $\mathrm{Cd}$ to its aboveground parts (Table 2).

Regarding $\mathrm{Pb}$ and $\mathrm{Ni}$, chamomile plants were also able to accumulate significant amounts, again mainly in the roots (Fig. 1B, C, Table 2). The translocation of $\mathrm{Pb}$ in the aboveground tissues was much lower, compared to $\mathrm{Cd}$. More specifically, even at the highest soil contamination level $(1800 \mathrm{ppm} \mathrm{Pb})$, the concentration of the metal in the flowers did not exceed the recommended by WHO levels $(10 \mathrm{mg} / \mathrm{kg}$ d.w.). The levels of the accumulated lead in the leaves exceeded the WHO limits only for the two highest $\mathrm{Pb}$ concentrations in the soil. In general, the same behaviour was observed for chamomile in the presence of $\mathrm{Ni}$ : most of the accumulated $\mathrm{Ni}$ was stored in the roots, whereas leaves and flowers showed lower $\mathrm{Ni}$ concentrations. BAF and TF values for flowers and leaves were very low for both $\mathrm{Pb}$ and $\mathrm{Ni}$, indicating the preferential accumulation of the metals in the roots of the plant. In general, BAF and TF values of $\mathrm{Cd}, \mathrm{Pb}$ and $\mathrm{Ni}$ for the flowers and leaves of chamomile follow the order $\mathrm{Cd}>\mathrm{Ni}>\mathrm{Pb}$. 


\subsubsection{Sage}

Fig. 1 (D, E, F) presents the accumulation of $\mathrm{Cd}, \mathrm{Pb}$ and $\mathrm{Ni}$, respectively, in the roots and leaves of sage. The major observation is that all three metals are accumulated mainly in the roots of the plants, same as chamomile. Sage roots accumulate in general more $\mathrm{Cd}$ than chamomile roots, however a much smaller fraction of the metal moved to the leaves of the plant (Table 2). The lower translocation of $\mathrm{Cd}$ in the leaves of sage compared to the leaves of chamomile is indicated by the lower BAF and TF values. It needs to be emphasized however, that only the control and marginally the lowest contamination level gave $\mathrm{Cd}$ concentration in the leaves which were lower than the values recommended by WHO, meaning that regardless the bioaccumulation and translocation factors, sage grown in Cd contaminated areas is potentially toxic if consumed by humans or animals. Regarding the other two metals, less $\mathrm{Pb}$ and Ni were accumulated, in general, in the roots of sage compared to the roots of chamomile, and even less amounts of these metals were transferred to the leaves of the plants. In our experiments, even at the highest soil contamination level, the concentration of $\mathrm{Pb}$ in the leaves of sage did not reach the highest recommended value of $10 \mathrm{mg} / \mathrm{kg} \mathrm{d}$.w. Sage can be considered as a metal excluder, due to accumulation of the examined metals in its roots, with lower metal accumulation capacity compared to chamomile.

\subsubsection{Thyme}

Data in Table 2 and in Fig. $1(\mathrm{G}, \mathrm{H}, \mathrm{I})$ indicate that thyme roots accumulate much less $\mathrm{Cd}$ compared to chamomile roots, but also to sage roots. However, the fraction of $\mathrm{Cd}$ which is translocated to the leaves of thyme is quite significant and the levels of $\mathrm{Cd}$ found in the leaves of all plants (even the controls) exceeded the WHO levels. The more efficient translocation of $\mathrm{Cd}$ to the aboveground parts of thyme compared to sage is depicted as higher TF values of the leaves of thyme (Table 2). The higher than the acceptable levels of $\mathrm{Cd}$ concentration in control samples were tested with plant and soil samples from mountainous areas of Chania prefecture and, as with chamomile, very low Cd levels were

\section{Chamomile}
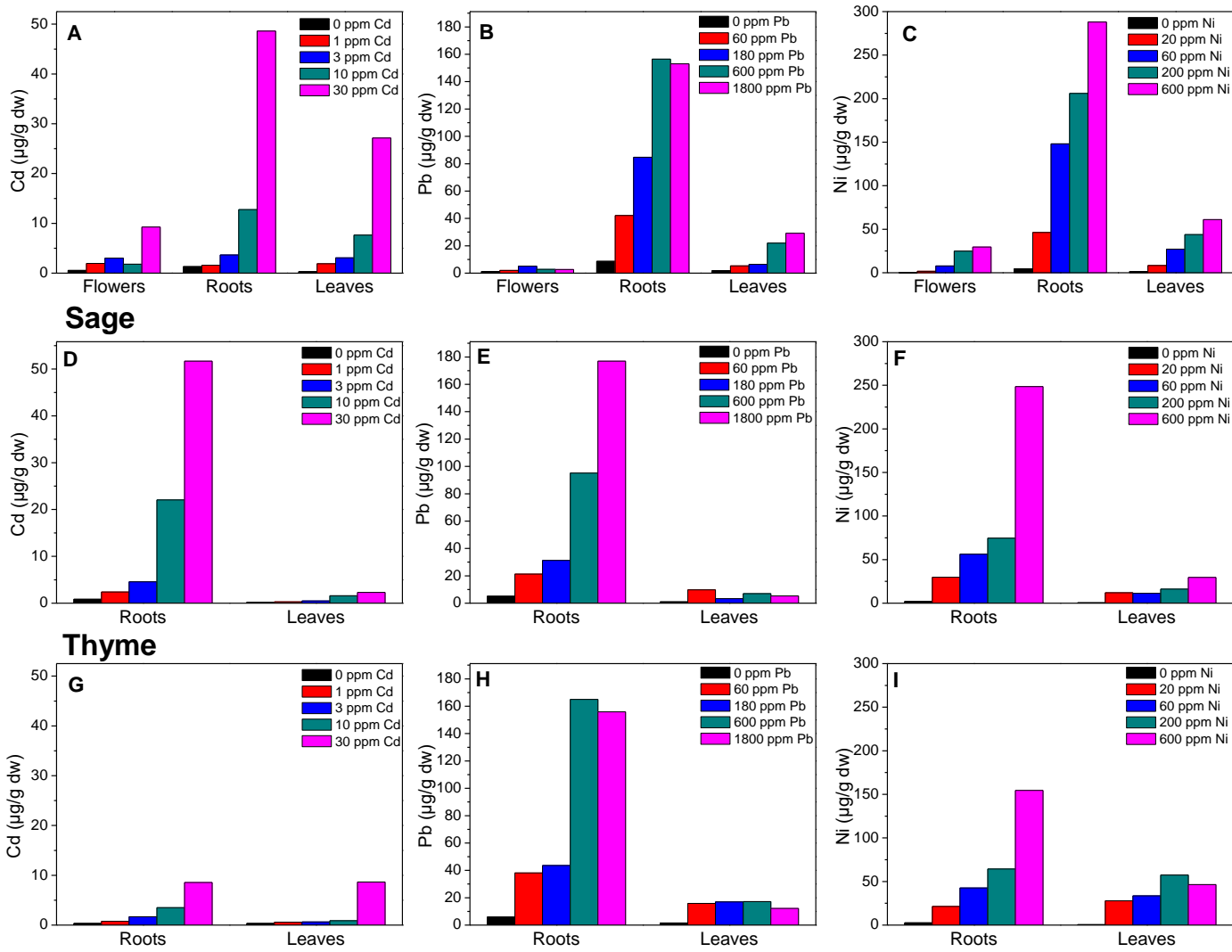

Figure 1. Accumulation of $\mathrm{Cd}(\mathrm{A}, \mathrm{D}, \mathrm{G}), \mathrm{Pb}(\mathrm{B}, \mathrm{E}, \mathrm{H})$ and $\mathrm{Ni}(\mathrm{C}, \mathrm{F}, \mathrm{I})$ in chamomile, sage and thyme tissues. 


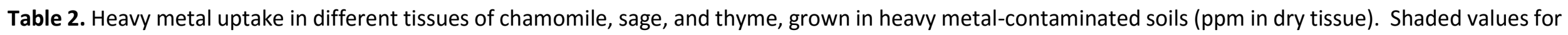
edible tissues are above the highest values recommended by WHO.

\begin{tabular}{|c|c|c|c|c|c|c|c|c|c|c|c|c|c|c|c|}
\hline \multirow{2}{*}{$\begin{array}{c}\begin{array}{c}\text { Added } \\
\text { metal } \\
\text { (ppm) }\end{array} \\
\text { Cd }\end{array}$} & \multicolumn{7}{|c|}{ Chamomile } & \multicolumn{4}{|c|}{ Sage } & \multicolumn{4}{|c|}{ Thyme } \\
\hline & $\begin{array}{l}\text { Roots } \\
\text { (ppm) }\end{array}$ & $\begin{array}{l}\text { Flowers } \\
\text { (ppm) }\end{array}$ & $\begin{array}{c}\text { BAF } \\
\text { flowers }\end{array}$ & $\begin{array}{c}\text { TF } \\
\text { flowers }\end{array}$ & $\begin{array}{l}\text { Leaves } \\
\text { (ppm) }\end{array}$ & $\begin{array}{c}\text { BAF } \\
\text { leaves }\end{array}$ & $\begin{array}{c}\text { TF } \\
\text { leaves }\end{array}$ & $\begin{array}{l}\text { Roots } \\
\text { (ppm) }\end{array}$ & $\begin{array}{l}\text { Leaves } \\
\text { (ppm) }\end{array}$ & $\begin{array}{c}\text { BAF } \\
\text { leaves }\end{array}$ & $\begin{array}{c}\text { TF } \\
\text { leaves }\end{array}$ & $\begin{array}{l}\text { Roots } \\
\text { (ppm) }\end{array}$ & $\begin{array}{l}\text { Leaves } \\
\text { (ppm) }\end{array}$ & $\begin{array}{c}\text { BAF } \\
\text { leaves }\end{array}$ & $\begin{array}{c}\text { TF } \\
\text { leaves }\end{array}$ \\
\hline 0 & 1.32 & 0.54 & - & 0.41 & 0.30 & - & 0.23 & 0.85 & 0.18 & - & 0.14 & 0.33 & 0.34 & - & 0.26 \\
\hline 1 & 1.57 & 1.96 & 1.96 & 1.25 & 1.88 & 1.88 & 1.20 & 2.41 & 0.29 & 0.29 & 0.12 & 0.75 & 0.57 & 0.57 & 0.76 \\
\hline 3 & 3.64 & 3.03 & 1.01 & 0.83 & 3.07 & 1.02 & 0.84 & 4.58 & 0.48 & 0.16 & 0.10 & 1.68 & 0.65 & 0.22 & 0.39 \\
\hline 10 & 12.7 & 1.79 & 0.18 & 0.14 & 7.63 & 0.76 & 0.60 & 22.1 & 1.60 & 0.16 & 0.07 & 3.50 & 0.87 & 0.09 & 0.25 \\
\hline 30 & 48.6 & 9.27 & 0.31 & 0.19 & 27.1 & 0.90 & 0.56 & 51.7 & 2.31 & 0.08 & 0.04 & 8.55 & 8.65 & 0.29 & 1.01 \\
\hline \multicolumn{16}{|l|}{$\mathbf{P b}$} \\
\hline 0 & 8.61 & 1.27 & - & 0.15 & 1.91 & - & 0.22 & 5.10 & 1.04 & - & 0.12 & 5.89 & 1.59 & - & 0.18 \\
\hline 60 & 42.1 & 2.01 & 0.03 & 0.05 & 5.35 & 0.09 & 0.13 & 21.3 & 9.74 & 0.16 & 0.46 & 38.1 & 15.9 & 0.26 & 0.42 \\
\hline 180 & 84.7 & 5.12 & 0.03 & 0.06 & 6.41 & 0.04 & 0.07 & 31.3 & 3.31 & 0.02 & 0.15 & 43.5 & 17.0 & 0.09 & 0.39 \\
\hline 600 & 156.5 & 2.72 & $<0.01$ & 0.02 & 21.9 & 0.04 & 0.14 & 95.1 & 6.95 & 0.01 & 0.07 & 165 & 17.2 & 0.04 & 0.10 \\
\hline 1800 & 153 & 2.62 & $<0.01$ & 0.02 & 29.2 & 0.02 & 0.19 & 177 & 5.31 & $<0.01$ & 0.03 & 156 & 12.2 & $<0.01$ & 0.08 \\
\hline \multicolumn{16}{|l|}{$\mathbf{N i}$} \\
\hline 0 & 4.47 & 0.15 & - & 0.03 & 1.43 & - & 0.32 & 2.05 & 0.57 & - & 0.13 & 2.63 & 0.55 & - & 0.12 \\
\hline 20 & 46.2 & 1.78 & 0.09 & 0.04 & 8.40 & 0.42 & 0.18 & 29.8 & 11.9 & 0.60 & 0.40 & 21.4 & 27.9 & 1.39 & 1.30 \\
\hline 60 & 148 & 7.88 & 0.13 & 0.05 & 27.1 & 0.45 & 0.18 & 56.2 & 11.3 & 0.19 & 0.20 & 42.6 & 33.5 & 0.56 & 0.79 \\
\hline 200 & 206 & 24.8 & 0.12 & 0.12 & 43.9 & 0.22 & 0.21 & 74.7 & 16.2 & 0.08 & 0.22 & 64.4 & 57.5 & 0.29 & 0.89 \\
\hline 600 & 288 & 29.6 & 0.05 & 0.10 & 61.2 & 0.10 & 0.21 & 248.5 & 29.5 & 0.05 & 0.12 & 154 & 46.5 & 0.08 & 0.30 \\
\hline
\end{tabular}


obtained. One important observation in Fig. $1 \mathrm{G}$ is the very high $\mathrm{Cd}$ concentration in the leaves of thyme grown on soil contaminated with $30 \mathrm{ppm} \mathrm{Cd}$. The BAF value in this condition was above 1 , which could by itself characterize thyme as $\mathrm{Cd}$ hyperaccumulator. This result strengthens the opinion that one cannot rely on the bioaccumulation or translocation factors obtained from limited experimental conditions in order to conclude for the behaviour of a plant or for the safety of its consumption. Regarding the other two metals, accumulation of $\mathrm{Pb}$ in thyme roots was comparable to that in chamomile roots, thus, in general, higher than sage roots. The major difference of thyme from the two other plants regarding lead, is that a much larger fraction of the metal was found in the leaves: all the $\mathrm{Pb}$ concentrations used in our experiment (except control) resulted in $\mathrm{Pb}$ concentrations in the leaves which were higher than the WHO levels. Certainly, thyme grown in $\mathrm{Pb}$-contaminated fields cannot be consumed. The roots of thyme accumulated less $\mathrm{Ni}$ than the other two plants, however, higher Ni levels (and TF values) were found in the leaves of thyme than the leaves of the other two plants. Nevertheless, BAF and TF values were higher than 1 only at the lowest Ni level, so thyme cannot be considered as a Ni hyperaccumulator.
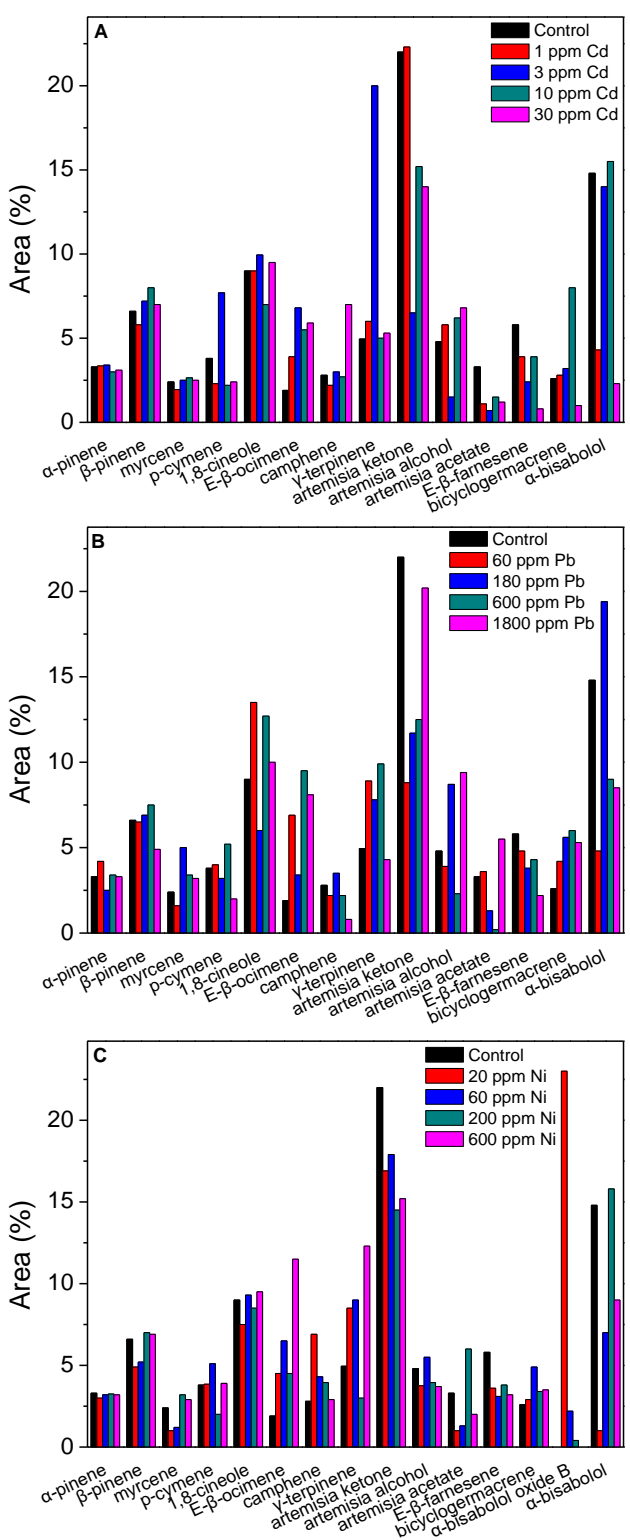

Figure 2. Percentage of important compounds in essential oils from control and $\mathrm{Cd}(\mathrm{A}), \mathrm{Pb}(\mathrm{B}), \mathrm{Ni}(\mathrm{C})$ contaminated chamomile
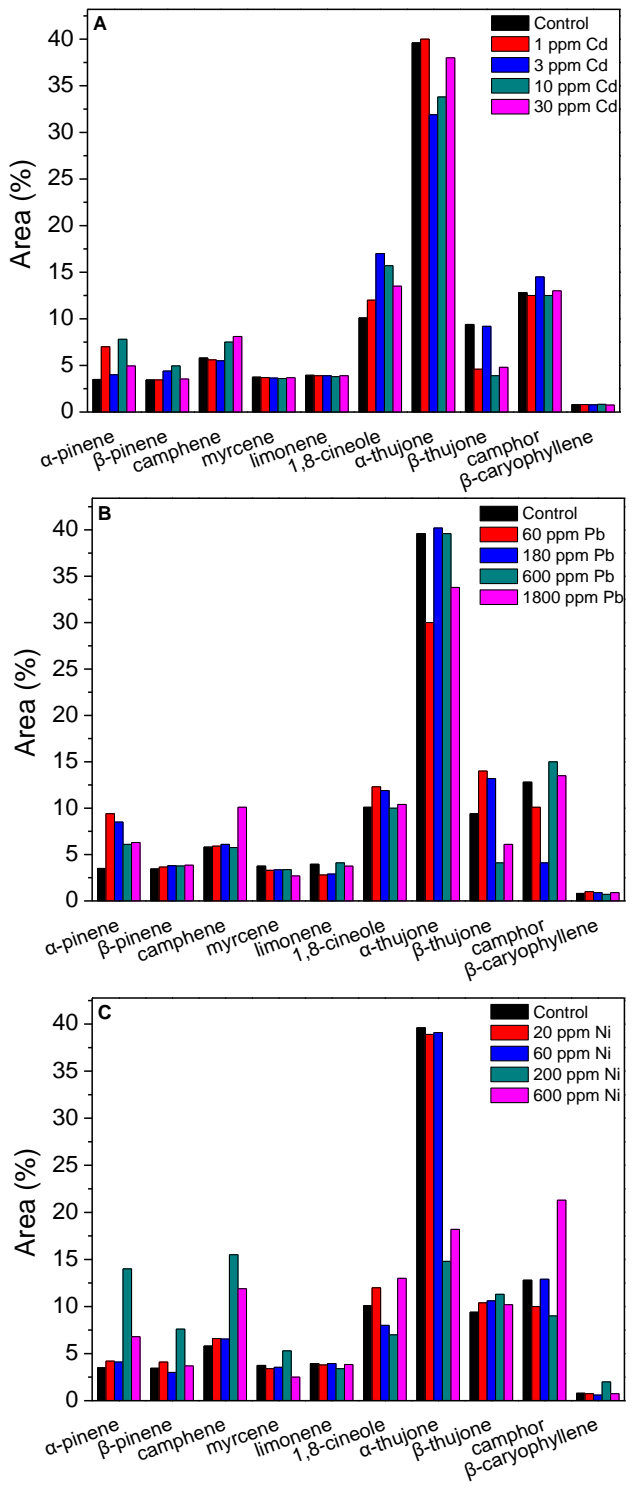

Figure 3. Percentage of important compounds in essential oils from control and $\mathrm{Cd}(\mathrm{A}), \mathrm{Pb}(\mathrm{B}), \mathrm{Ni}$

(C) contaminated sage 


\subsection{Essential oil content and heavy metal contamination.}

The essential oil profile of the three plants under study was obtained qualitatively and quantitatively by head space analysis and GC-MS, respectively. Data for about 40 compounds were obtained for each plant, and the results for the most abundant compounds are presented in Fig. 2 (chamomile flowers), Fig. 3 (sage), and Fig. 4 (thyme). In general, in all the examined conditions, the essential oil content was not affected significantly by the presence of the heavy metals in the soils.
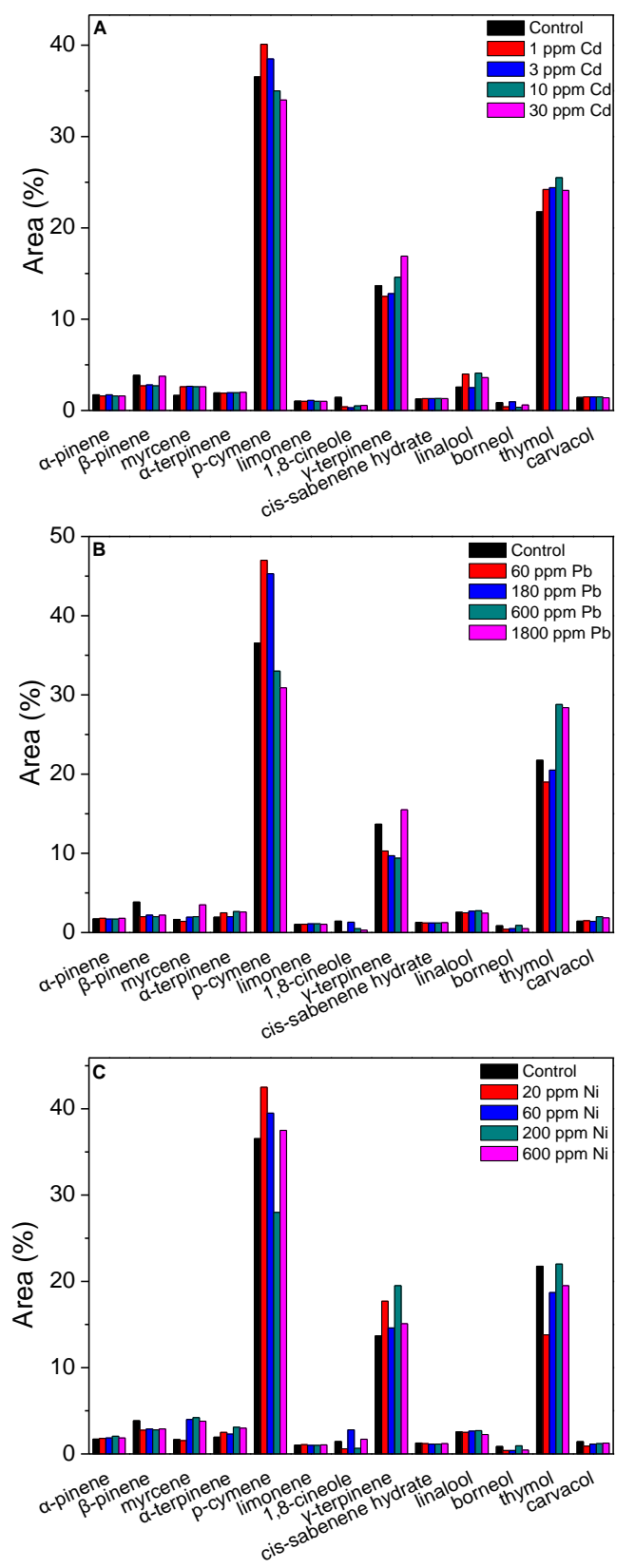

Figure 4. Percentage of important compounds in essential oils from control and $\mathrm{Cd}(\mathrm{A}), \mathrm{Pb}(\mathrm{B}), \mathrm{Ni}(\mathrm{C})$ contaminated thyme

The most important compounds of chamomile essential oil are $\alpha$-pinene, $\beta$-pinene, $p$-cymene, 1,8 cinneole, artemisia ketone, E- $\beta$-farnesene, and $\alpha$-bisabolol. Their relative abundances, along with the relative abundances of some other compounds are presented in Fig. 2 for plants grown on $\mathrm{Cd}(\mathrm{A}), \mathrm{Pb}(\mathrm{B})$, and $\mathrm{Ni}$ (C) contaminated soil. Data in Fig. $2 \mathrm{~A}$ indicates that $\mathrm{Cd}$ contamination had in general minor effects on the essential oil of chamomile: increasing amounts of $\mathrm{Cd}$ in the flowers of chamomile either did not 
alter the concentration of compounds (i.e. $\alpha$-pinene, $\beta$-pinene, myrcene, $p$-cymene, 1,8-cinneole), or there was some increase (E- $\beta$-ocimene, camphene), decrease (artemisyl acetate, $E$ - $\beta$-farnesene) or noncanonical alteration (artemisia alcohol, $\alpha$-bisabolol) in the concentration of certain compounds. $\mathrm{Pb}$ contamination (Fig. 2B) did not cause any serious change in this picture, except the gradual decrease of camphene and the increase of the bicyclogermacrene content. The major alteration due to $\mathrm{Ni}$ contamination (Fig $2 \mathrm{C}$ ) was the appearance of $\alpha$-bisabolol oxide B, with a peak at $20 \mathrm{ppm} \mathrm{Ni}$ in the soil and the relative stabilization of the artemisia ketone content.

Fig. $3(A, B, C)$ presents data on the relative content of sage essential oil from leaves. The modifications of the essential oil content due to heavy metal contamination were even less, compared to chamomile. The only noticeable changes $\mathrm{Cd}$ contamination caused were the slight increase of 1,8-cineole and the decrease of $\beta$-thujone contents at some $\mathrm{Cd}$ contamination levels. Pb contamination caused either slight increase, or slight decrease of $\beta$-thujone content, whereas $\mathrm{Ni}$ contamination caused increase of $\alpha$-pinene and camphene contents at higher contamination levels, but had no effect on $\beta$-thujone.

The profiles of essential oils from thyme leaves are presented in Fig. $4(A, B, C)$. As with the other two plants, changes of the content of the essential oils due to heavy metal contamination are very small and without any effect on the quality of the oils. The only noticeable changes were observed for $p$-cymene content at the two lower contamination levels of $\mathrm{Cd}$ and $\mathrm{Pb}$ and for thymol, which exhibits an increase at the two higest concentrations of $\mathrm{Pb}$. Ni effects on thyme essential oil content (Fig. 4C) are also minor: increase of myrcene at higher Ni levels, small decrease of p-cymene concentration at $200 \mathrm{ppm} \mathrm{Ni}$ and a small decrease of thymol concentration at $20 \mathrm{ppm} \mathrm{Ni}$ contamination levels.

The heavy metal content of the essential oil extracts was determined by ICP-AES spectrometry. In all the extracts, the concentrations of the three heavy metals under examination were at the levels of the limits of detection of the method. This result, along with the observation that the quality of the essential oils, as defined by their content of major ingredients, of the three aromatic plants under examination is not affected by the soil contamination by $\mathrm{Cd}, \mathrm{Pb}$, and $\mathrm{Ni}$ is very significant, since it indicates that, at least under certain conditions, contaminated areas could be used to produce goods with high added value, like essential oils from aromatic plants.

Our observations are in agreement with similar studies by Zheljazkov et al., (2006, 2008a,b), Kováčik et al., (2006) and Stancheva et al., (2010), on different aromatic plants and/or different contamination conditions. These groups also concluded that several aromatic plants they tested, either in pot experiments similar to ours (Zheljazkov et al., 2006), experiments with soil from contaminated fields (Zheljazkov et al., 2008b, Stancheva et al., 2010), or hydroponics experiment (Kováčik et al., 2006, Zheljazkov et al., 2008a) accumulated significant amounts of heavy metals, mainly in their root systems, with fractions of heavy metals to be found in the aboveground parts of the tested plants.

\section{Conclusions}

Aromatic plants grown in heavy metal-contaminated fields can accumulate considerable amounts of the toxic metals, depending on the level of contamination, as well as several chemical and physicochemical properties of the contaminated soil. In our study, the three aromatic plants under examination (chamomile, sage and thyme), grew normally, without any significant morphological or physiological symptoms due to soil contamination, proving that they are tolerant to a wide range of concentrations of $\mathrm{Cd}, \mathrm{Pb}$ and $\mathrm{Ni}$ in the soil. They accumulated most of the toxic metals in their root system, with the aboveground parts accumulating a relatively small amount of each metal. Thus, as indicated by the Bioaccumulation Factors (BAF) and Translocation Factors (TF) determined in this study, these plants cannot be considered as hyperaccumulators, capable for phytoremediation of contaminated field, but rather as excluders (Masarovičová et al., 2010). In general, aromatic plants cannot be considered as phytoextractors, not only because most of the accumulated heavy metals are stored in their roots, but also because their biomass is low. These results clearly exclude aromatic plants grown on heavy metal contaminated fields (at least the plants we examined), from either phytoremediation processes, or from 
consumption as food supplements or herbs, or for herbal teas, as some of their heavy metal content is expected to be extracted to the concoction (Schilcher and Peters 1990; Chizzola et al. 2008; Arpadjan et al. 2008; Affholder et al. 2013). However, careful analysis of the extracted essential oils from plants grown at all the conditions tested showed that neither the quality and the content of the oils were altered significantly, nor detectable amounts of heavy metals were found in these oils. These results are also in agreement with Zheljazkov et al., (2006, 2008a,b), who examined other aromatic plants or some plants common with our study but in different experimental conditions and heavy metal concentrations, with Stancheva et al., (2010) who examined the sage essential oil quality on a contaminated field experiment, with Lal et al., (2013) who examined essential oils and heavy metal accumulation in lemon grass, and with Affholder et al., (2013) who examined the quality of essential oil extracted from leaves of rosemary grown in an old smelter site. Our study supports the idea of utilizing heavy metal contaminated areas for the production of alternative goods, more specifically products from aromatic and medicinal plants with high added value, such as essential oils, the market of which expands globally. It is very important, however, to keep in mind several facts regarding this issue: The potential of using heavy metal-contaminated fields for the production of essential oils from specific aromatic plants opens a way for converting a previously unproductive piece of land to a productive one, without however giving solution to the serious environmental problem of heavy metal contamination. It needs to be emphasized that heavy metal accumulation in plants and translocation to the aboveground tissues are metal- and plant- dependent processes. Also, the bioavailable concentrations of the heavy metals in a specific contaminated field depend strongly on the chemical and physicochemical properties of the existing soil (Alloway, 2013). Finally, depending on the case and the origin of the soil contamination, besides the specific heavy metals, contaminated soils may contain other substances, more or less toxic, which may also affect the quality and the content of the essential oils to be produced. Thus, before the beginning of an aromatic plant cultivation on a heavy metal contaminated site, all the above mentioned parameters need to be taken into account, and detailed analyses of the soil in the site is absolutely necessary. A small size, piloting cultivation, in which several aromatic plants can be tested, is probably the safest way to make the best decisions for a specific land use. Taking all the measures to prevent consumption of the aromatic plants by humans is also an unquestionable requirement.

\section{References}

Affholder M.C., Prudent P., Masotti V., Coulomb B., Rabier J., Nguyen-The B. and Laffont-Schwob I. (2013), Transfer of metals and metalloids from soil to shoots in wild rosemary (Rosmarinus officinalis L.) growing on a former lead smelter site: Human exposure risk, Science of the Total Environment, 454-455, 219-229.

Ali H., Khan E. and Sajad A. (2013), Phytoremediation of heavy metals - Concepts and applications, Chemosphere 91, 869-881.

Alloway B.J. (2013), Sources of heavy metals and metalloids in soils, In: Heavy Metals in Soils, Trace Metals and Metalloids in Soils and their Bioavailability, $3^{\text {rd }}$ ed, Alloway B.J. (Editor). Springer Science+Business Media, Dordrecht, pp. 11-50.

Amacher M.C. (1996), Nickel, cadmium and lead In: Methods of Soil Analysis, Part 3, Sparks D.L., Page A.L., Helmke P.A., Loeppert R.H. (Eds), SSSA, Madison WI, pp. 739-768.

Andersen E. and Kupper H. (2013), Cadmium toxicity in plants, In: Cadmium: From Toxicity to Essentiality, Metal lons in Life Sciences 11, Sigel A., Sigel H., Sigel R.K.O. (Eds), Springer Science+Business Media, Dordrecht, pp. 395-413.

Arpadjan S., Çelik G., Taşkesen S. and Güçer Ş. (2008), Arsenic, cadmium and lead in medicinal herbs and their fractionation, Food and Chemical Toxicology, 46, 2871-2875.

ATSDR, Agency for Toxic Substances and Disease Registry, http://www.atsdr.cdc.gov/ (last accessed July 20, 2013).

Bolan N., Kunhikrishnan A., Thangarajan R., Kumpiene J., Park J., Makino T., Kirkham M.B. and Scheckel K. (2014), Remediation of heavy metal(loid)s contaminated soils--to mobilize or to immobilize? Journal of Hazardous Materials, 266, 141-166. 
Butcher D.J. (2009), Phytoremediation of lead in soil: recent application and future prospects, Applied Spectroscopy Reviews, 44, 123-139.

Cataldo D.A. and Wildung R.E. (1978), Soil and plant factors influencing the accumulation of heavy metals by plants, Environmental Health Perspectives, 27, 149-159.

Chen C., Huang D. and Liu J. (2009), Functions and toxicity of nickel in plants: recent advances and future prospects, Clean, 37, 304-313.

Chizzola R. and Mitteregger U.S. (2005), Cadmium and zinc interactions in trace element accumulation in chamomile, Journal of Plant Nutrition, 28, 1383-1396.

Chizzola R., Michitsch H. and Mitteregger U.S. (2008), Extractability of selected mineral and trace elements in infusions of chamomile, International Journal of Food Sciences and Nutrition, 59, 451-456.

Cunningham S.D. and Ow D.W. (1996), Promises and prospects of phytoremediation, Plant Physiology, 110, 715-719.

Greipsson S. (2011), Phytoremediation, Nature Education Knowledge, 3(10):7

Kováčik J., Tomko J., Bačkor M. and Repčák M. (2006), Matricaria chamomilla is not a hyperaccumulator, but tolerant to cadmium stress, Plant Growth Regulation, 50, 239-249.

Kováčik J., Klejdus B., Hedbavny J. and Bačkor M. (2009), Nickel uptake and its effect on some nutrient levels, amino acid contents and oxidative status in Matricaria chamomilla plants, Water Air and Soil Pollution, 202, 199-209.

Kováčik J., Grúz J., Klejdus B., Štork F. and Kedbavny J. (2012), Accumulation of metals and selected nutritional parameters in the field-grown chamomile anthodia, Food Chemistry, 131, 55-62.

Lal K., Yadav R.K., Kaul R., Bundela D.S., Inayat Khan M., Chaudhary M., Meena R.L., Dar S.R. and Singh G. (2013), Productivity, essential oil yield, and heavy metal accumulation in lemon grass (Cymbopogon flexuosus) under varied wastewater-groundwater irrigation regimes, Industrial Crops and Products, 45, 270-278.

Lindsay W.L. and Norvell W.A. (1978), Development of a DTPA soil test for zinc, iron, manganese, and copper, Soil Science Society of American Journal, 42, 421-428.

Lu Y. and Foo L.Y. (2001), Antioxidant activities of polyphenols from sage (Salvia officinalis), Food Chemistry, 75, 197-202.

Mahar E., Wang P., Ali A., Awasti, M.K., Lahori A.H., Wang Q., Li R., and Zhang Z. (2016), Challenges and opportunities in the phytoremediation of heavy metals contaminated soils: A review, Ecotoxicology and environmental safety, 126, 111-121.

Masarovičová E. and Králová K. (2007), Medicinal plants - past, nowadays, future, Acta Horticulturae (ISHS), 749, 19-27.

Masarovičová E., Králová K. and Kummerová M. (2010), Principles of classification of medicinal plants as hyperaccumulators or excluders, Acta Physiologiae Plantarum, 32, 823-829.

McGrath S.P. and Zhao F.J. (2003), Phytoextraction of metals and metalloids from contaminated soils, Current Opinion in Biotechnology, 14, 277-282.

McKay D.L. and Blumberg J.B. (2006), A review of the bioactivity and potential health benefits of chamomile tea (Matricaria recutita L), Phytotherapy Research, 20, 519-530.

Meagher R.B. (2000), Phytoremediation of toxic elemental and organic pollutants, Current Opinion in Plant Biology, 3, 153-162.

Raskin I. and Ensley B.D. (2000), Phytoremediation of toxic metals: Using plants to clean up the environment, John Wiley and Sons, INC., NY.

Rubió L., Motilva M.-J. and Romero M.-P. (2013), Recent advances in biologically active compounds in herbs and spices: A review of the most effective antioxidant and anti-inflammatory active principles, Critical Reviews in Food Science and Nutrition, 53, 943-953.

Schilcher H. and Peters H. (1990), Proposal of limiting values for lead and cadmium content of medicinal plants and their pharmaceutical preparations (in German), Pharm. Ind., 52 916-921.

Smolders E. and Mertens J. (2013), Cadmium, In: Heavy Metals in Soils, Trace Metals and Metalloids in Soils and their Bioavailability, $3^{\text {rd }}$ ed, Alloway B.J. (Editor), Springer Science+Business Media, Dordrecht, pp. 283-311. 
Stancheva I., Geneva M., Hristozkova M., Markovska Y. and Salamon I. (2010), Antioxidant capacity of sage grown on heavy metal-polluted soil, Russian Journal of Plant Physiology, 57, 799-805.

Steinnes E. (2013), Cadmium, In: Heavy Metals in Soils, Trace Metals and Metalloids in Soils and their Bioavailability, $3^{\text {rd }}$ ed, Alloway, B.J. (Editor), Springer Science+Business Media, Dordrecht, pp. 395-409.

Tapsel L.C., Hemphill I., Cobiac L., Patch C., Sullivan D.R., Fenech M.F., Roodenrys S., Keogh J.B., Clifton P.M., Williams P.G., Fazio V.A. and Inge K.E. (2006), Health benefits of herbs and spices: the past, the present, the future, Medical Journal of Australia, 185(4 Suppl), S4-24.

Tran T.A. and Popova L.P. (2013), Functions and toxicity of cadmium in plants: recent advances and future prospects, Turkish Journal of Botany, 37, 1-13.

World Health Organization, WHO, (1998), Determination of Arsenic and Heavy Metals, In: Quality Control Methods for Medicinal Plant Material, Genova, pp. 62-63.

Zheljazkov V.D., Craker L.E. and Xing B. (2006), Effects of Cd, Pb, and Cu on growth and essential oil contents in dill, peppermint, and basil, Environmental and Experimental Botany, 58, 9-16.

Zheljazkov V.D., Craker L.E., Xing B., Nielsen N.E. and Wilcox A. (2008a), Aromatic plant production on metal contaminated soils, Science of the Total Environment, 395, 51-62.

Zheljazkov V.D., Jeliazkova E.A., Kovacheva N. and Dzhurmanski A. (2008b), Metal uptake by medicinal plant species grown in soils contaminated by a smelter, Environmental and Experimental Botany, 64, 207-216. 